研究

\title{
シリコンを含む $\mathbf{P} / \mathbf{M}$ 二相ステンレス鋼の機械的性質と耐食性
}

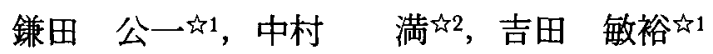

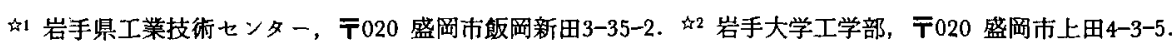

\section{Mechanical Properties and Corrosion Resistances of P/M Two-phase Stainless Steels with Silicon}

\author{
Koichi Kamada ${ }^{\hbar 1}$, Mitsuru Nakamura ${ }^{\not 2}$ and Toshihiro Yoshida ${ }^{\hbar 1}$ \\ H1 I Iwate Industrial Research Institute, 3-35-2 liokashinden, Morioka 020. \\ \& Fac. Eng., Iwate University, 4-3-5 Ueda, Morioka 020.
}

Received August 17, 1995

\begin{abstract}
SYNOPSIS
Influence of the addition of silicon on mechanical properties and corrosion resistances of $P / M$ austenitic stainless steels was investigated by means of microstructual examinations, calorimetric analysis and X-ray analysis. Silicon addition to P/M austenitic stainless steels makes the sintering in the duplex structure of austenite $(\gamma)$ and ferrite $(\alpha)$ possible by the liquid phase sintering with a eutectic liquid. For example, addition of $4 \mathrm{mass} \% \mathrm{Si}$ results in the formation of about $40 \mathrm{vol} \%$ of ferrite. Tensile strength of sintered steels increases with increased silicon content, and the maximum strength (940MPa) was obtained in the steel with $4 \mathrm{mass} \% \mathrm{Si}$ which was sintered for $3.6 \mathrm{ks}$ at $1623 \mathrm{~K}$. On the other hand, elongation of sintered steels tends to increase with rising sintering temperature. The maximum elongation $(\mathbf{4 7 . 5 \% )}$ was obtained in the steel with $2 \mathrm{mass} \% \mathrm{Si}$ which was sintered for $3.6 \mathrm{ks}$ at $1673 \mathrm{~K}$. The sintered steel with $2 \mathrm{mass} \% \mathrm{Si}$ was found to have excellent corrosion resistance in a boiling solution of $65 \% \mathrm{HNO}_{3}$ : The corrosion rate of the steel was very small in comparison with the sintered SUS304L steel, but it was three times larger than that of a SUS304L steel produced by ingot metallurgy. However, further addition of silicon causes a decline in corrosion resistance probably due to a decrease in the green density.
\end{abstract}

KEY WORDS

addition of silicon, duplex stainless steel, mechanical properties, corrosion resistance, sintered density

\section{1 緒言}

著者らは，これまでにオ一ステナイト系ステンレ ス鋼粉末に嘲素 (B) およびりん（P) を微量添 加することにより，焼結ステンレス鋼の高強度，高 延性化および耐食性について検討し各々報告してき $た^{1-33}$. その結果, 従来の焼結ステンレス鋼の機械 的性質および而食性を大きく上回る優れた焼結材料 を得ることができたしかし，溶製ステンレス鎆と 比較した場合，機械的性質ではほぼ同等の値が得ら れるものの，耐粓界腐食性において，特にP 添加
焼結ステンレス鋼は腐食環境下でのアノード反応促 進作用により耐食性が劣化することもわかっだ'.

一方, フェライト相 $(\alpha)$ およびオーステナイト 相 $(\gamma)$ とからなる溶製二相ステンレス鋼は強度が フェライト系, オーステナイト系ステンレス鎉のい ずれよりも高く，さらに耐食性においても粒界腐食， 孔食, 応力腐食割れ等に優れた性質を有しているこ とは広く知られているい?.

本研究は，オーステナイト系ステンレス銿粉末に フェライト化促進元素であるシリコン（Si ）を添 
加し，焼結過程での共晶反応による緻密化挙動を利 用し機械的性質を向上を図るとともに，マトリック ス中にフェライト相を生成させ組織を二相化するこ とによる耐食性への影響について検討した。

\section{2 実験方法}

原料粉末として， -100mesh の水アトマイズステ ンレス鋼粉 ${ }^{23}$ (大平洋金属 (株) 製：SUS304L) と添加元素粉として -200meshのフェロシリコン粉

（福田金属箔粉工業（株）製： $\mathrm{Fe}-\mathrm{Si}$ ）を用いた。 なお，Si の含有量は $42.8 \mathrm{mass} \%$ である。これら粉 末を V 型混合機を用いて $1.8 \mathrm{ks}$ 混合した. 混合割合 は, Si として $1 \sim 4 \mathrm{mass} \%$ の範囲で $1 \mathrm{mass} \%$ 間隔 で 4 条件とした. 次に, 得られた混合粉を JS Z 2550 の引張試験片および腐食試験用として衝撃試 験片形状に各々 $20 \mathrm{~g} ， 40 \mathrm{~g}$ 秤量し，金型により成 形圧力 $490 \mathrm{MPa}$ で王縮成形した. 圧粉体は真空下

（2Pa 以下）で, 昇温速度を $139 \mathrm{~K} / \mathrm{ks}$, 冷却速度 を $1073 \sim 773 \mathrm{~K}$ 間で $136 \mathrm{~K} / \mathrm{ks}$ の炉冷とし, 焼結温 度を $1473 \sim 1673 \mathrm{~K}$ の範囲で 5 条件変化させ, 各温 度で $3.6 \mathrm{ks}$ 保持した.

各条件で得られた焼結体について，引張試験およ び沸騰 $65 \%$ 硝酸溶液による粒界腐食試験（JIS G 0573 ）を行った。腐食試験は前報 ${ }^{3)}$ と同様の前処 理を行い，浸漬時間を $6 ， 12 ， 24 ， 48 \mathrm{~h}$ とし試 験後の腐食減量を测定した。

各試験でのデータを基に，Si 添加した焼結組織 の二相化による影響について検討するため，ミクロ 組織観察，焼結過程における示差熱分析（DTA） および EPMA による面分析および X 線回折による $\alpha$ 相の定量分析等を行った.

\section{3 実験結果}

\section{1 機械的性質に及ぼす $\mathrm{Si}$ 添加量の影響}

Fig.1 に引張強さに及ぼす Si 添加量と焼結温度の 関係を示す.いずれの $\mathrm{Si}$ 添加量においても焼結温 度が高いほど高強度となる．また Si 添加量が増加 するほどより低温の焼結条件でも高強度を示す，本 実験において，4mass\%Si，焼結温度 $1623 \mathrm{~K}$ の条 件のとき，最大強度 $940 \mathrm{MPa}$ を得た。 これは，ス テンレス鋼溶製材よりかなり高い引張強さである. なお 3mass\%および $4 \mathrm{mass} \% \mathrm{Si}$ の試料は焼結温度 $1673 \mathrm{~K}$ の条件で溶融変形し，これ以上の温度では 良好な形状の焼結体が得られない。

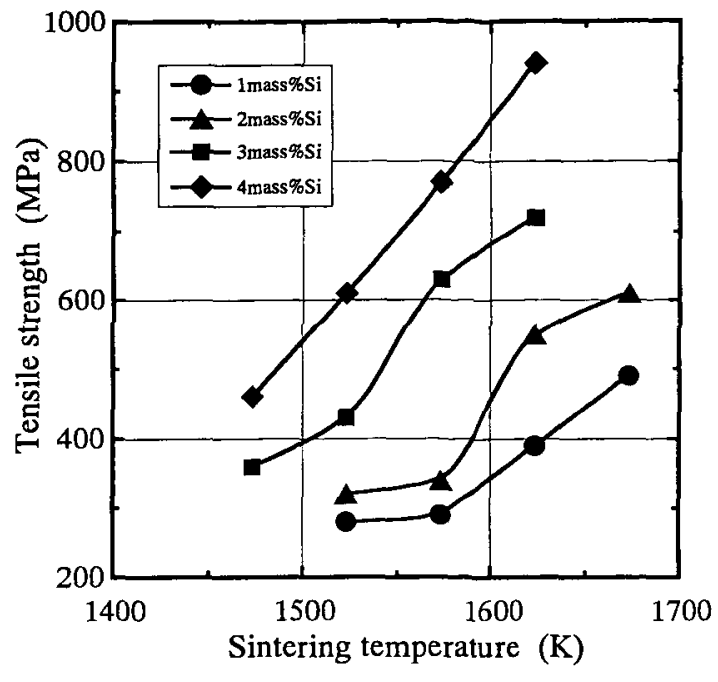

Fig.1 Relation between tensile strength and sintering temperature in $\mathrm{P} / \mathrm{M}$ stainless steels with silicon.

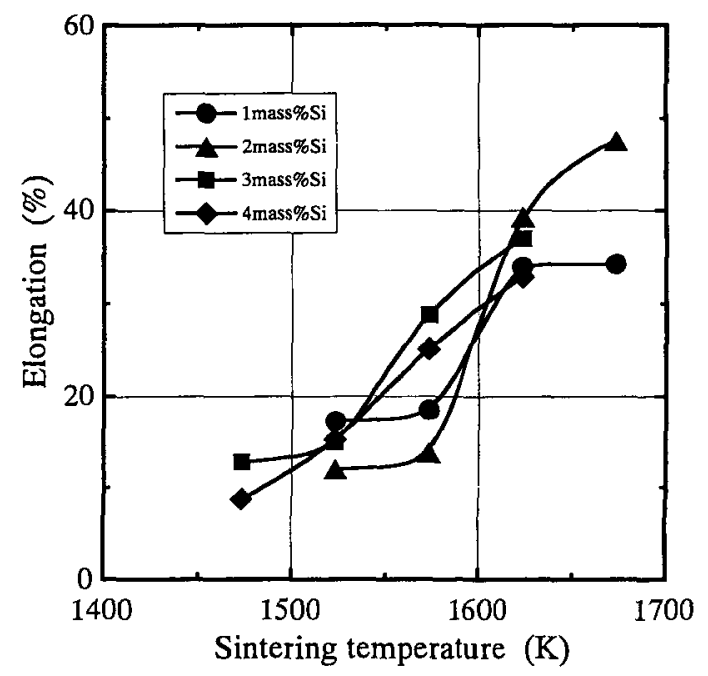

Fig.2 Relation between elongation and sintering temperature in P/M stainless steels with silicon.

Fig.2に同様に伸びに及ぼす Si 添加量と焼結温度 の影響を示す．いずれの Si 添加量においても焼結 温度が高いほど高延性を示し，本実験内において $2 \mathrm{mass} \% \mathrm{Si}$ ，焼結温度 $1673 \mathrm{~K}$ の条件で最大 $47.5 \%$ を得た. しかし Fig.1で示した引張強さのデータと は異なり Si 添加量の影響は明瞭ではなかった。ま た，最大伸びを示した 2 mass\%Si 材でも $1573 \mathrm{~K}$ 以 下の温度では，液相が少ないことや粉末粒子間の焼 結が不十分なため低い伸び值であった。 


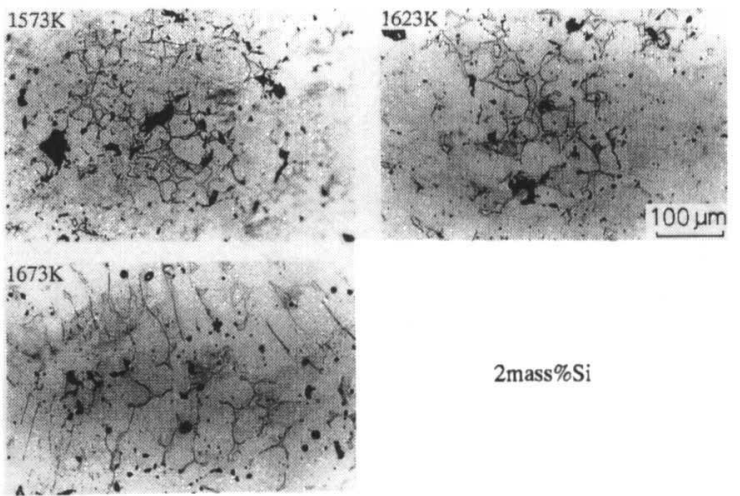

Photo.1 Microstructures of a $\mathrm{P} / \mathrm{M}$ stainless steel with $2 \mathrm{mass} \% \mathrm{Si}$.

Photo.1 は伸び値で良好な結果を得た $2 \mathrm{mass} \% \mathrm{Si}$ 材の各焼結温度でのミクロ組織である. 焼結温度 1673K の組織は，ポアが結晶粒界に少なく，かつ 球状化しており， Si 添加で生成した $\alpha$ 相と思われ る晶出相も均一に分散している。 それに対し $1573 \mathrm{~K}$ および $1623 \mathrm{~K}$ 焼結のものはポア径が大きく， かつ晶出相は量も少なく局所的に生成しており, 焼 結温度が低すぎるものと思われた。このことから， 高延性化にはマトリックスである母相 $\gamma$ 相の緻密化 とともにポアの減少, 晶出相の均一分布が必要であ ると考える.

$3.2 \mathrm{Si}$ 添加によるミクロ組織の二相化のメカニズ 厶

Fig.3 に Si 添加量が異なる焼結体の X 線回折パ夕 ーンを示す. 無添加材では, $\gamma$ 相ピークのみである のに対し, $\mathrm{Si}$ 添加材では $\alpha$ 相のピークも認められ, 添加量が増加するとその強度も高くなり， Si 添加 によるミクロ組織の二相 $(\gamma+\alpha)$ 化が確喼される. Fig.4 は X 線回折結果より算出した $\alpha$ 相体皘率と $\mathrm{Si}$ 添加量の関係を示したものである. 焼結温度とは関 係なく, $\mathrm{Si}$ 添加量の増加とともに $\alpha$ 相体積率は増 加し， $4 \mathrm{mass} \% \mathrm{Si}$ のとき $\alpha$ 相は約 $40 \%$ に達する. ただし，焼結温度の影響はPhoto.1 に示すように $\alpha$ 相をマトリックス中に均一分布させる作用として認 められた.

Photo.2 は，4mass\%Si， 1623K の条件で焼結し た試料の SEM による二次電子線像（SEI）と面分 析結果である. $\alpha$ 相として晶出した領域に Si およ び Cr の濃化がみられ，一方 Ni はこれらとは反対 に, $\gamma$ 相で濃化傾向を示すことがわかる.

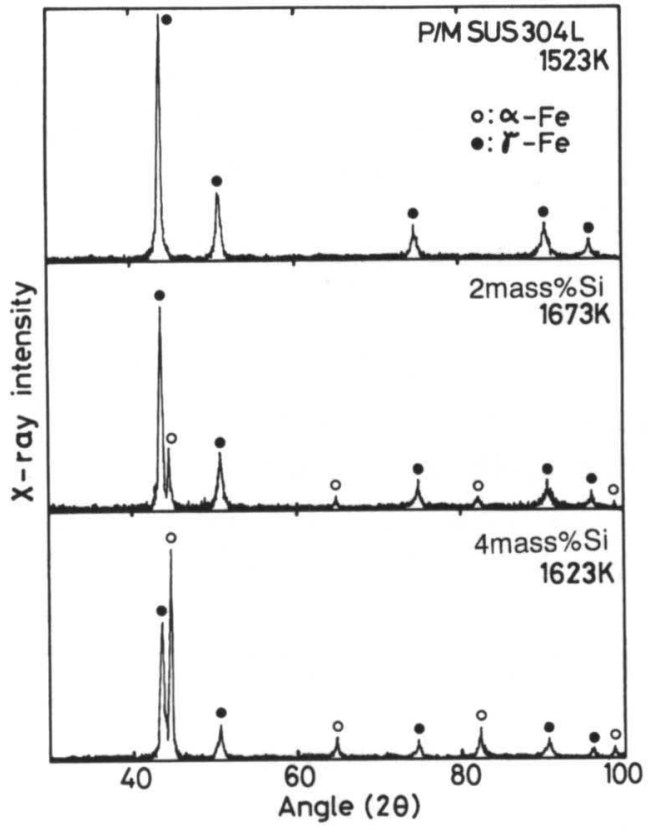

Fig.3 X- ray diffraction patterns of $\mathrm{P} / \mathrm{M}$ stainless steels with silicon. (Cu Target)

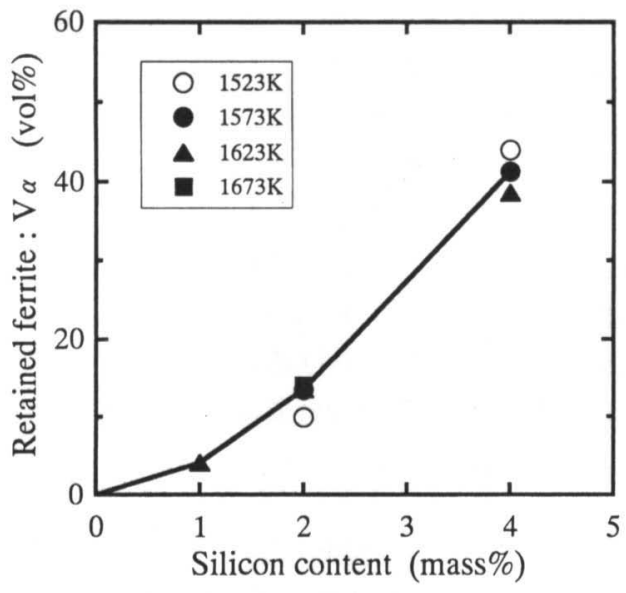

Fig.4 Relation between the volume fraction of retained ferrite and silicon contents in $\mathrm{P} / \mathrm{M}$ stainless steels.

Fig.5 に 1mass\%Si を添加した圧粉体の真空中, 昇温速度 $0.17 \mathrm{~K} / \mathrm{s}$ での DTA 結果を示す. マトリッ クスと Fe-Si 粉末の共晶反応による融液の生成を示 す吸熱ピークが $1522 \mathrm{~K}$ 近傍に確認された. このこ とから，焼結過程で $\alpha$ 相生成元素として作用する $\mathrm{Si}^{4)}$ を多く含む液相にマトリックス $(\gamma)$ 中の $\mathrm{Si}$ 

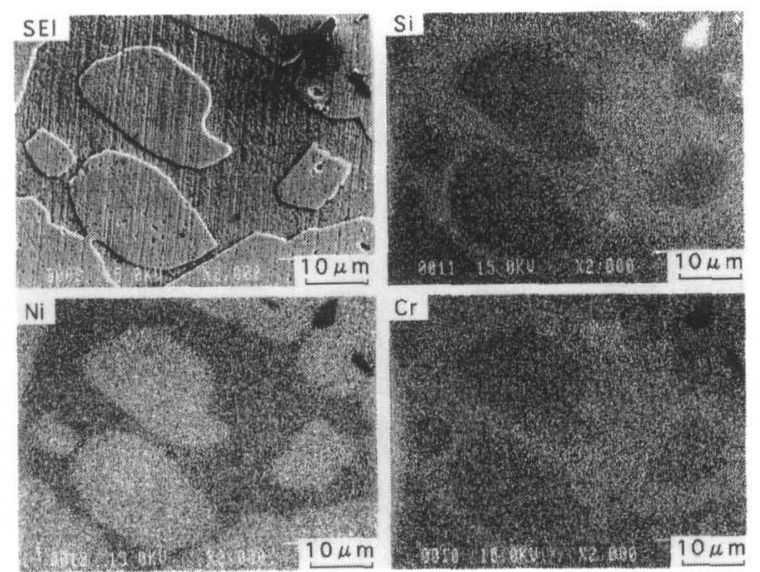

Photo.2 EPMA analysis in a P/M stainless steel with $2 \mathrm{mass} \% \mathrm{Si}$.

之同様な $\alpha$ 相生成元素である $\mathrm{Cr}^{4)}$ の拡散が進行し, 明瞭な $\alpha$ 相の生成に至ったもの之考えられる.

\section{3 二相化による耐食性への影響}

今回腐食試験に供した試料は次のとおりである. まず $\mathrm{Si}$ 添加材は伸び, 強度で各々最大值を示した $2 \mathrm{mass} \% \mathrm{Si}$ および $4 \mathrm{mass} \% \mathrm{Si}$ のものとし, 比較材と して $1523 \mathrm{~K}$ で焼結した Si 無添加焼結ステンレス鋼 （無添加材）と溶製ステンレス鋼（溶製材）を用い た.

Fig.6 に浸漬時間と腐食速度の関係を示す．溶製

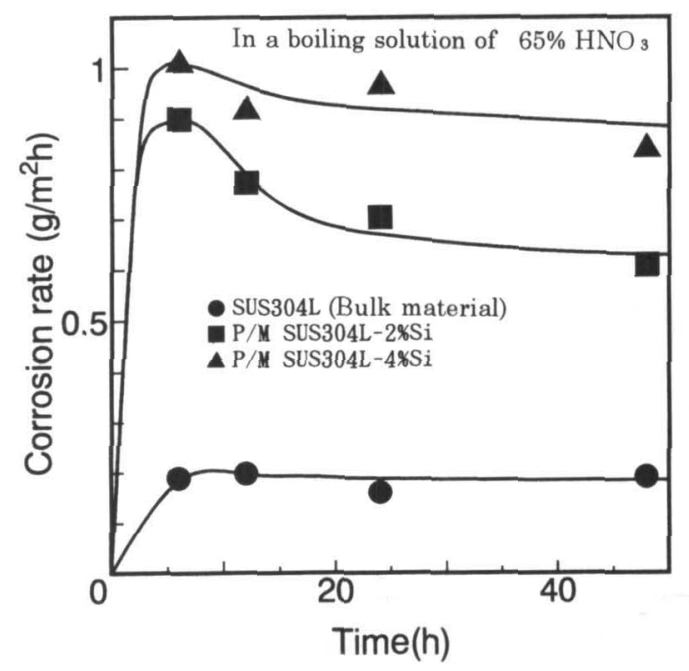

Fig.6 Relation between corrosion rate and immersion time in the intergranular corrosion test.

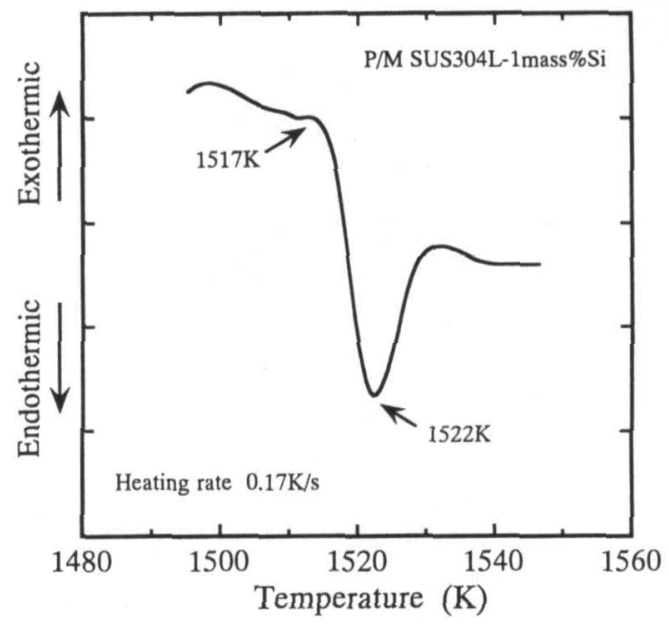

Fig.5 Differential thermal analysis curve of a P/M stainless steel with $1 \mathrm{mass} \% \mathrm{Si}$.

材（SUS304L）が浸漬時間に拘らずほぼ一定の腐 食速度を示すのに対し， Si を添加した $\mathrm{P} / \mathrm{M}$ 材はい ずれも浸漬の初期段階において溶製材の約 5 倍の腐 食速度を示し, $48 \mathrm{~h}$ 経過後は $2 \mathrm{mass} \% \mathrm{Si}$ 添加材で 溶製材の約 3 倍, $4 \mathrm{mass} \% \mathrm{Si}$ 添加材では約 4 倍の腐 食速度となり, Si 量が増えるほど腐食速度は大き くなる傾向を示した．また， Si 無添加の P/M 材は 試験開始から激しく腐食され, 比較不可能であった.

Photo. 3 は $48 \mathrm{~h}$ 経過後の各試験片の腐食表面近傍 の断面ミクロ組織である. いずれも特に粒界の優先 腐食等によるクラックは認められないが, ポアの存
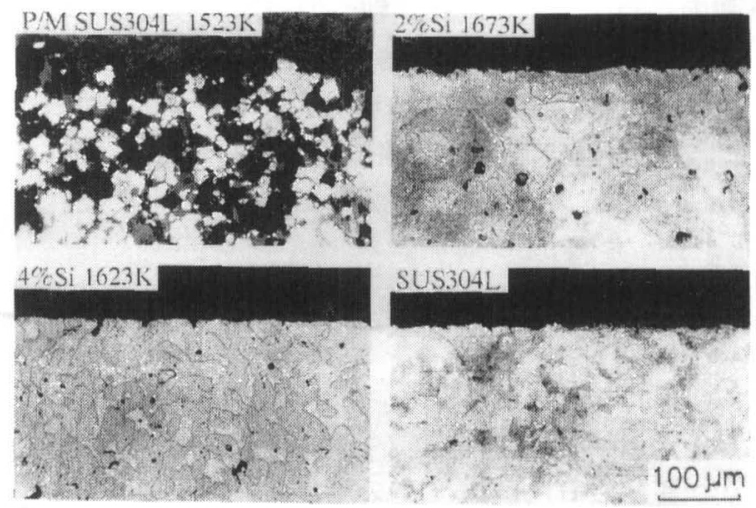

Boiling $65 \% \mathrm{HNO}_{3}$ solution - $48 \mathrm{~h}$

Photo.3 Microstructures of 4 kinds of stainless steels : Showing cross-sections near the surface of specimens with the intergranular corrosion test. 
在が耐食性に重要な影響を与えることが示唆された。 すなわち，組織の二相化 $(\alpha+\gamma$ 相) よりも，焼結 密度の向上（ポアの減少）か耐食性の改善には有効 であることがわかった.

Fig.7は 48 時間経過後の溶製材（SUS304L）の 腐食速度を 1 としたときの $\mathrm{Si}$ 添加 $\mathrm{P} / \mathrm{M}$ 材と既報 ${ }^{3}$

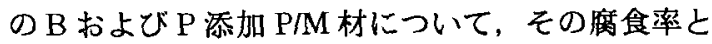
相対密度を比較したものである．Si および B 添加 材では相対密度が高いほど

腐食率が低く，耐食性が良好であり，この比較から も上記のことが示唆される。一方， P 添加 $\mathrm{P} / \mathrm{M}$ 材 は高密度であるが，結晶粒界に晶出するりん化物が アノード反応促進物質として作用し，他とは腐食挙 動が異なることから直接比較することはできないも のと考える.

今回，4mass\%Si 添加材の焼結密度が $2 \mathrm{mass} \% \mathrm{Si}$ 添加材に比へ低かった原因としては，2mass\%Si 添 加材に比べ焼結温度が $50 \mathrm{~K}$ 低いこと，さらに添加 元素粉末である $\mathrm{Fe}-\mathrm{Si}$ 粉の添加量増加が金型成形時 の圧縮性や充填性を悪化させ ${ }^{5)}$ ，压粉密度の低下を 招いたことが考えられる．耐食性の向上には，焼結 温度をこれ以上上げられないことから，成形時にお ける圧粉密度の改善が必要でこれにより $2 \mathrm{mass} \% \mathrm{Si}$ 添加材と同等以上の耐食性が得られるも のと推察される.

\section{4 結 言}

Si 添加したオーステナイト系焼結ステンレス 鋼の二相 $(\gamma+\alpha)$ 化挙動や焼結体の強度とその 耐食性について検討した結果, 以下の結論を得た.

（1）引張強さは Si 添加量とともに上昇し，かつ 低温の焼結温度でも高強度を示す。本実験では $4 \mathrm{mass} \% \mathrm{Si}$ ，焼結温度 $1623 \mathrm{~K}$ の条件で最大強度 940MPa を得た.

（2）伸びはいずれの Si 添加量においても焼結温 度が高いほど高延性を示し，本実験では $2 \mathrm{mass} \% \mathrm{Si}$ ， 焼結温度 $1673 \mathrm{~K}$ の条件 で, 最大伸び $47.5 \%$ を得た。

(3) Si 添加によるミク口組織の二相 $(\gamma+\alpha)$ 化が確認され，Si 添加量の増加に伴い $\alpha$ 相の体積 率も增加し，4mass $\% \mathrm{Si}$ の とき $\alpha$ 相は約 $40 \%$ に達 した. $\alpha$ 相は焼結過程で発生した波相への $\alpha$ 相生成 元素（ $\mathrm{Si} ， \mathrm{Cr}$ ）の濃化によるものと考える.

(4) 沸滕 $65 \%$ 硝酸溶液による粓界腐食試験の結 果, $2 \mathrm{mass} \% \mathrm{Si}$ 添加材， $4 \mathrm{mass} \% \mathrm{Si}$ 添加材，無添加

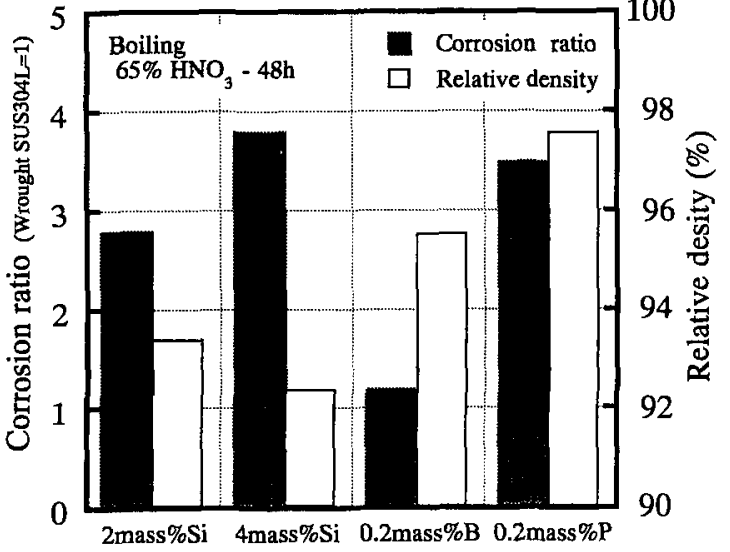

Fig.7 Relation between corrosion ratio and relative density in 4 kinds of P/M stainless steels.

材の順で $\mathrm{P} / \mathrm{M}$ 材の耐食性は劣化傾向を示し， $48 \mathrm{~h}$ 経過後で $\mathrm{Si}$ 無添加の溶製材と比較すると， $2 \mathrm{mass} \% \mathrm{Si}$ 添加材では溶製材の䄪 3 倍， $4 \mathrm{mass} \% \mathrm{Si}$ 添加材では約 4 倍の腐食速度となった。

（5） $\alpha$ 相の晶出による二相化によって耐食性の改 善が期待されたが，Si 添加用の Fe-Si 粉末増加 は成形性を悪化させ最終的に焼結密度の低下を生じ ることがわかった：このことから，耐食性の面では 二相化よりも焼結体の高緻密化が有効であると考え る.

\section{謝辞}

本研究の遂行にあたり，終始実験に協力された岩 手大学工学部学生遠藤弘一君 [現：日立粉末冶金 （株）]に心より感謝申し上げます。

\section{文献}

1) 中村，鎌田：粉体および粉末治金，38（1991） 22 .

2）中村，鎌田，堀江，平塚 : 粉体および粉末冶金, $39(1992), 24$.

3 ）中村，鎌田，堀江，平塚 : 粉体および粉末冶金, 40 ( 1993$) ， 444$.

4）長谷川正義：ステンレス鋼便覧，日刊工業新聞 社, (1975)，421。

5) W.F.Wang and Y.L.Su : Powder Metallurgy, 29 ( 1986$), 269$. 